\title{
The morphology, arrangement, and ultrastructure of a new type of microtrich sensilla in marine isopods (Crustacea, Isopoda)
}

Valiallah Khalaji-Pirbalouty

\begin{abstract}
Background: Microtrich sensilla are a special type of cuticular structures found on the external surface of amphipod and isopod crustaceans. These cuticular microstructures, being important for systematic and phylogenetic studies, display a wide diversity of shapes and distribution among different taxa. Here, the microstructure of the cuticular surface of 11 marine isopod species was investigated by scanning electron microscopy.
\end{abstract}

Results: On the dorsal and lateral sides of all the taxa examined, only one distinct type of microtrich sensillum was found in the regular rows. While this structure is very similar to that of the Ib microtrich type (sensu Crustaceana 13:100-106, 1988), however, it is distinct from the previous type, in which it has an elongate cuticular ring or specialized collar encircling the shaft base of the microtrichs. The findings indicate that different taxa of marine isopods may show a new type of microtrich sensilla differing in morphology and arrangement.

Conclusions: The findings indicate that different taxa of marine isopods may show a new type of microtrich sensilla differing in morphology and arrangement.

Keywords: Isopoda; Marine; Cuticular surface; Scanning electron microscopy

\section{Background}

Examination of cuticular surface features of crustaceans, especially Peracarida, has been conducted for many years. Fish (1972) described the setae of the aquatic isopod Eurydice pulchra Leach, 1815 on the basis of size as either macrotrichs or microtrichs. Powell and Halcrow (1982) described the surface microstructures of several marine littoral and terrestrial isopods using SEM, and Oshel and Steele (1988) and Oshel et al. (1988) described and discussed the setae and microtrich sensilla of some amphipods. In most cases, these studies were conducted with an emphasis on only one type of cuticular structure, viz., tricorn setae (Holdich and Lincoln 1974; Schmalfuss 1978), sensory spines (Brandt 1988), pores (Halcrow and Bousfield 1987; Khalaji-Pirbalouty and Sari 2004, 2006; Khalaji-Pirbalouty and Sari 2006), or microtrichs (Oshel et al. 1988; Platvoet 1985; Steele

Correspondence: khalajiv@yahoo.com

Department of Biology, Faculty of Science, Shahrekord University, P.O. Box 115 Shahrekord, Iran
1991; Olyslager and Williams 1993). Recently, Zimmer et al. (2009) described variation of five different kinds of cuticular structures for hyallelid amphipods, including 30 types of setae, four types of microtrich, and three types of pores. Of those, microtrich sensilla were found only on aquatic crustaceans, e.g., gammaridean amphipods and marine isopods; there is no report of these structures in terrestrial isopods. Fish (1972) used the term microtrich to refer to setae less than $10 \mu \mathrm{m}$ in length. Later, Oshel et al. (1988) defined microtrichs as setae less than $25 \mu \mathrm{m}$ in length with specialized sockets, and they divided microtrichs into two types, I and II, based on the socket morphology. Type I has a socket bearing a bowl-shaped, shallow depression, with a dome on one edge and is formed by 3 to 4 epidermal cells. Microtrich type II has a simple and circular socket. Type I microtrichs were further subdivided into three types (Ia, Ib, and Ic) on the basis of the setal morphology: Ia with a terminal pore directed to one side of the seta, Ib with long filaments radiating from a hood that may be one to two or more times as long as the setal shaft, and 
Ic a short and plumose setae whose filaments are either restricted to the apical end of the setal shaft or originate from the distal third of the shaft (see Oshel et al. 1988, pages 102 and 103, Figures two (a,b), three $(\mathrm{a}, \mathrm{b})$, and four). Microtrich sensilla type II are defined as short, longitudinally compressed seta with a bifurcate tip. Type II microtrichs also were called slide-line organ or flattened microtrichs on gammaridian amphipods by Platvoet (1985) and Platvoet et al. (2007). More recently, Kaim-Malka (2010) introduced the term 'unispathes' (along with spatheform organ for whole set of structures) instead of previous terms and despite the fact that spatheform is a common name for plants of the genus Arisaema. These structures have been found in many amphipods and also in some marine isopods (e.g., Platvoet 1985; Laverack and Barrientos 1985; Halcrow and Bousfield 1987; Oshel et al. 1988; Olyslager and Williams 1993; Kaim-Malka 2010). This paper describes the morphology and arrangement of a new kind of Ib microtrich sensilla sensu (Oshel et al. 1988) on marine isopods.

\section{Methods}

Specimens for this study were collected primarily from intertidal and subtidal habitats along the Iranian coastline of the Persian Gulf. Collecting techniques included sieving sand and washing algae and sea grass, as well as direct capture. Excirolana sp., Dynamenella granulata (Javed and Ahmed 1988), Sphaeroma khalijfarsi (Khalaji-Pirbalouty and Wägele 2010), Sphaeroma walkeri (Stebbing 1905), Sphaeromopsis sarii Khalaji-Pirbalouty and Wägele 2010), Cymodoce sp., Lanocira sp., and Atarbolana sp. were collected from the beach of the Persian Gulf. In addition, specimens of Excirolana orientalis (Dana 1853), Sphaeromopsis amathitis (Holdich and Jones 1973), and Sphaeromopsis mourei Loyola e Silva 1960 were obtained from Copenhagen Museum and the Museum of Tropical Queensland. Of these, Excirolana sp., E. orientalis, Lanocira sp., and Atarbolana sp. belong to the family Cirolanidae, and D. granulata, S. khalijfarsi, S. walkeri, Cymodoce sp., S. sarii, S. amathitis, and S. mourei belong to the family Sphaeromatidae. Scanning electron microscopy (SEM) specimens were washed in chilled $1 \%$ sodium acetate solution for $10 \mathrm{~min}$ and then cleaned using an ultrasonic cleaner to remove the attached sediment and debris from the cuticle. After the specimens were dehydrated in an ethanol series and after a final 100\% ethanol, they were transferred to $100 \%$ hexamethyldisilazane (HMDS) through a three-graded series of ethanol-HMDS mixtures (100\% E 2:1, 1:1, 1:2, 100\% HMDS) in a fume hood. For the final step, the specimens were immersed in a HMDS container for 15 to $60 \mathrm{~min}$, depending on their size. The samples were then mounted on stubs using double-sided carbon tapes before being coated with gold in a sputter coater to $40-\mathrm{nm}$ thickness. The SEM micrographs were taken using a Hitachi S-2460 N SEM (Tokyo, Japan).

\section{Results}

On the cuticular surface of all the examined specimens, only one distinct type of structure was found in regular rows on the dorsal and lateral sides of the specimens. These structures are very similar to type Ib microtrichs (sensu Oshel et al. 1988) by having a socket with a shallow depression, a long shaft with a branch of relatively long filaments radiating from the distal part. In contrast to previously described Ib microtrichs, the socket here has an elongate cuticular ring or specialized collar that encircles the shaft base. The shape of the socket, the polygons or knobs on the adjacent cuticular depressions, the collars, shafts, and the distal filaments all show variation among the examined taxa (Table 1). Furthermore, the arrangement and number of rows of these cuticular structures are variable among different genera or among species of the genus. However, dorsal and lateral groups

\section{Table 1 Description of microtrich structures on the cuticular surface of some representatives of marine isopods}

\begin{tabular}{|c|c|c|}
\hline Species & Description & NF \\
\hline $\begin{array}{l}\text { Excirolana } \\
\text { orientalis }\end{array}$ & $\begin{array}{l}\text { Cuticular depressions are furnished with three } \\
\text { to four knobs arranged in a semi-circular row; } \\
\text { collar short, oval, anterior margin shorter than } \\
\text { posterior one; shaft short with a tuft of long } \\
\text { filaments (Figures 2B and 3B). }\end{array}$ & $\approx 30$ \\
\hline Excirolana sp. & $\begin{array}{l}\text { Cuticular depressions are furnished with } \\
\text { three to five knobs arranged in a semi- } \\
\text { circular row; collar short, anterior margin } \\
\text { shorter than posterior one; shaft short with } \\
\text { a tuft of long filaments (Figures } 2 \mathrm{~A} \text { and } 3 \mathrm{~A} \text { ). }\end{array}$ & $\approx 30$ \\
\hline Lanocira sp. & $\begin{array}{l}\text { Simple cuticular depression; collar very short, } \\
\text { oval; shaft very short with a tuft of long } \\
\text { filaments (Figure } 2 \text { C). }\end{array}$ & $\approx 12$ \\
\hline Atarbolana sp. & Collar very short, round; shaft long. & $\approx 5$ \\
\hline Sphaeromopsis sarii & $\begin{array}{l}\text { Shallow, flower-shaped cuticular depression; } \\
\text { collar spool-shaped, large; shaft large with a } \\
\text { tuft of long filaments (Figures 2D,E and 3D). }\end{array}$ & $\approx 8$ \\
\hline S. amathitis & $\begin{array}{l}\text { Shallow, flower-shaped cuticular depression; } \\
\text { collar spool-shaped, large; shaft large with } \\
\text { a tuft of long filaments (Figure 3E). }\end{array}$ & $\begin{array}{l}10 \\
\text { to } \\
12\end{array}$ \\
\hline S. mourei & $\begin{array}{l}\text { Shallow, flower-shaped cuticular depression; } \\
\text { collar spool-shaped, large; shaft large with } \\
\text { a tuft of long filaments (Figure 3F). }\end{array}$ & $6-8$ \\
\hline $\begin{array}{l}\text { Sphaeroma } \\
\text { khalijfarsi }\end{array}$ & $\begin{array}{l}\text { Collar short, shaft long with long filaments } \\
\text { (Figures } 2 \mathrm{~F} \text { and } 4 \mathrm{~A} \text { ). }\end{array}$ & $\approx 8$ \\
\hline S. walkeri & $\begin{array}{l}\text { Collar short; shaft long with long filaments } \\
\text { (Figure 4B). }\end{array}$ & $\begin{array}{l}4 \text { to } \\
5\end{array}$ \\
\hline Cymodoce sp. & $\begin{array}{l}\text { Collar medium, shaft very long with very } \\
\text { long filaments (Figures } 2 \mathrm{G} \text { and } 4 \mathrm{E} \text { ). }\end{array}$ & 5 \\
\hline $\begin{array}{l}\text { Dynamenella } \\
\text { granulata }\end{array}$ & $\begin{array}{l}\text { Collar medium, shaft short with long } \\
\text { filaments (Figure } 4 \text { C). }\end{array}$ & 5 \\
\hline
\end{tabular}

$\mathrm{NF}$, number of distal filaments. 


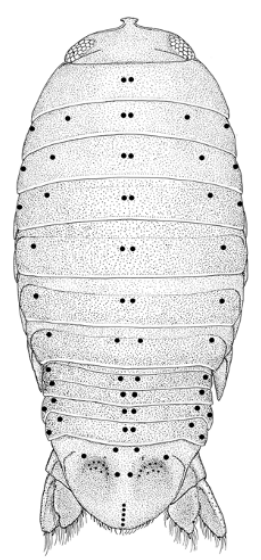

$\overline{(A)}$

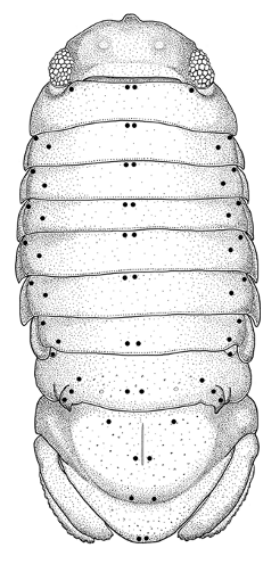

(B)

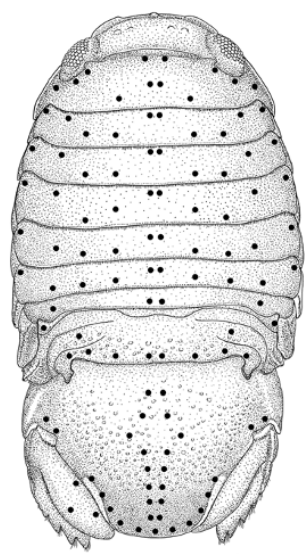

(C)

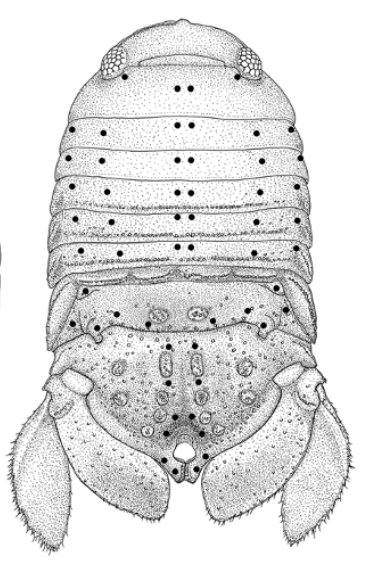

(D)

Figure 1 Dorsal view of the species (black circles indicate the position of the microtrichs). (A) Excirolana sp. (from Persian Gulf).

(B) Sphaeromopsis sarii. (C) Sphaeroma khalijfarsi. (D) Dynamenella granulata. Scale bars $=1 \mathrm{~mm}$.
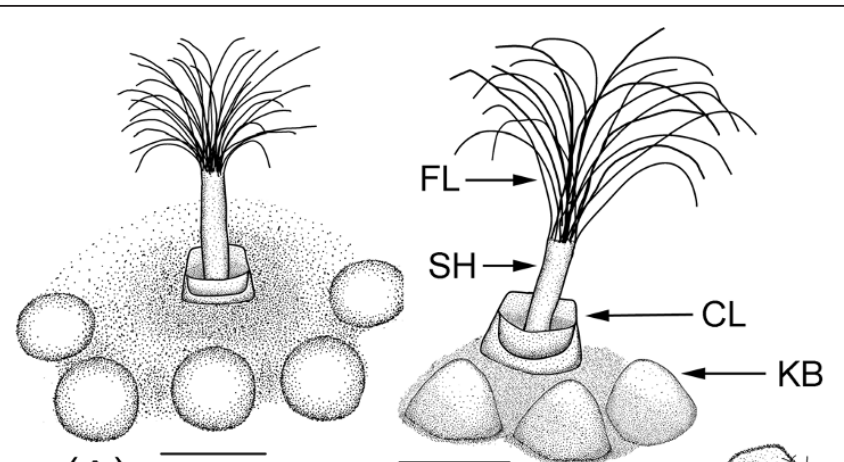

(c)

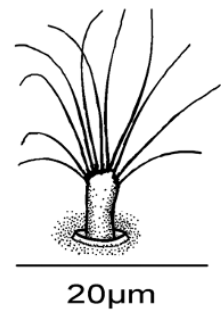

(A) $\overline{10 \mu m}$
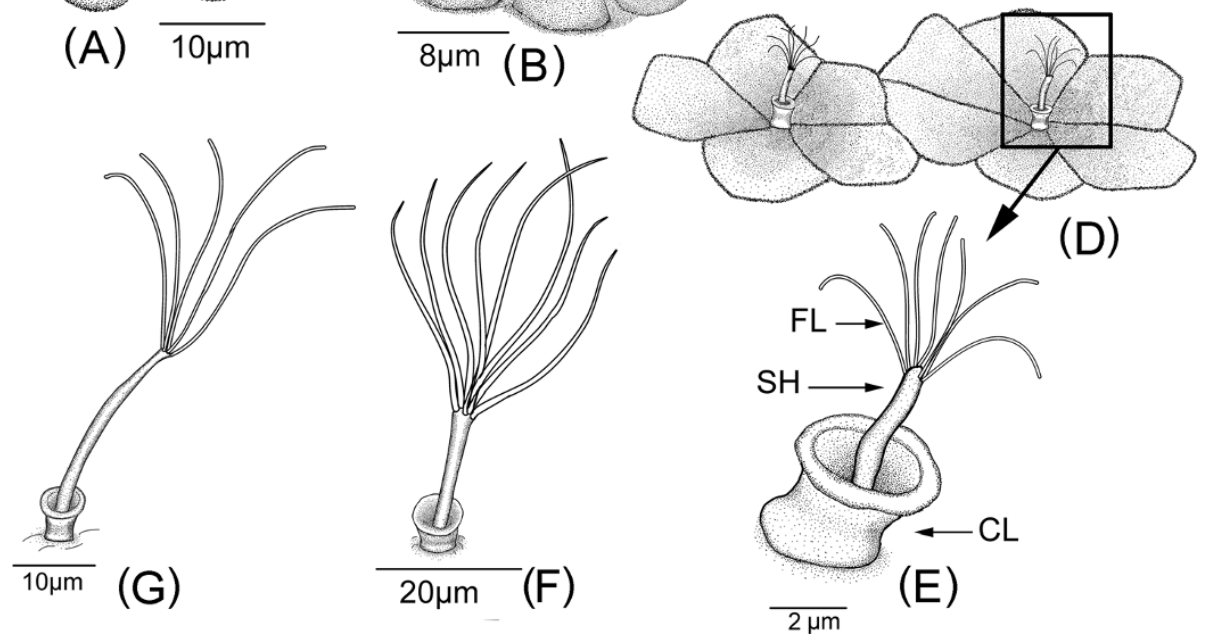

Figure 2 Schematic drawings of the microtrich structures. (A) Excirolana sp., (B) Excirolana orientalis (the cuticular depressions are furnished with three to five knobs arranged in a semi-circular row; in both species, each microtrich has a short collar, elongate shaft, and a tuft of long filaments), (C) Lanocira sp. (with very short collar and shaft, long filaments), (D and E) Sphaeromopsis sarii (shallow flower-shaped cuticular depressions on mid-dorsal surface of pereonite 1; collar spool-shaped, large; shaft large with a tuft of a few long filaments); (F) Sphaeroma khalijfarsi (with short collar, long shaft and filaments); (G) Cymodoce sp. (with medium collar, very long shaft and filaments); CL, Collar; SH, shaft; FL, filament; KB, knob. 
of these structures show near perfect symmetry. For example, E. orientalis Dana 1853 and Excirolana sp. from the Persian Gulf have two rows of these structures very close to each other on the mid-dorsal surface, one row on each dorsolateral side and one row on each lateral side (Figure 1A). On the pleotelson, there are two pairs of dorsal structures, a lateral pair, a dorsal row posteriorly, and several smaller structures on two depressions of the pleotelson (Figure 1A). The specimens of both species of Excirolana (from the Persian Gulf, New Guinea, and Philippines) have a microtrich that is encircled by a short collar, bearing an elongate shaft and a tuft of long filaments (approximately 30). In both species of Excirolana, the cuticular depressions are furnished with three to five knobs arranged in a semi-circular row (Figures 2A,B and $3 \mathrm{~A}, \mathrm{~B})$. Lanocira sp. (Figure 2C) has a microtrich that is encircled by a very short oval collar, bearing a small shaft and a tuft of long filaments (approximately 12), and microtrichs of Atarbolana sp. possess a very short and round collar with an elongate shaft and approximately five distal filaments (Figure 3C). In all examined species of the genus Sphaeromopsis, microtrichs are located in six rows: two close rows on mid-dorsal surface and two rows on each lateral side (Figure 1B), and each structure consists of a shallow flower-shaped cuticular depression (Figure 2D) and elongated spool-shaped cuticular collar (Figures 2E,D and 3D). In S. sarii (Figures 2E and 3D) and S. mourei (Figure 3F), each shaft has a tuft of 6 to 8 filaments on the
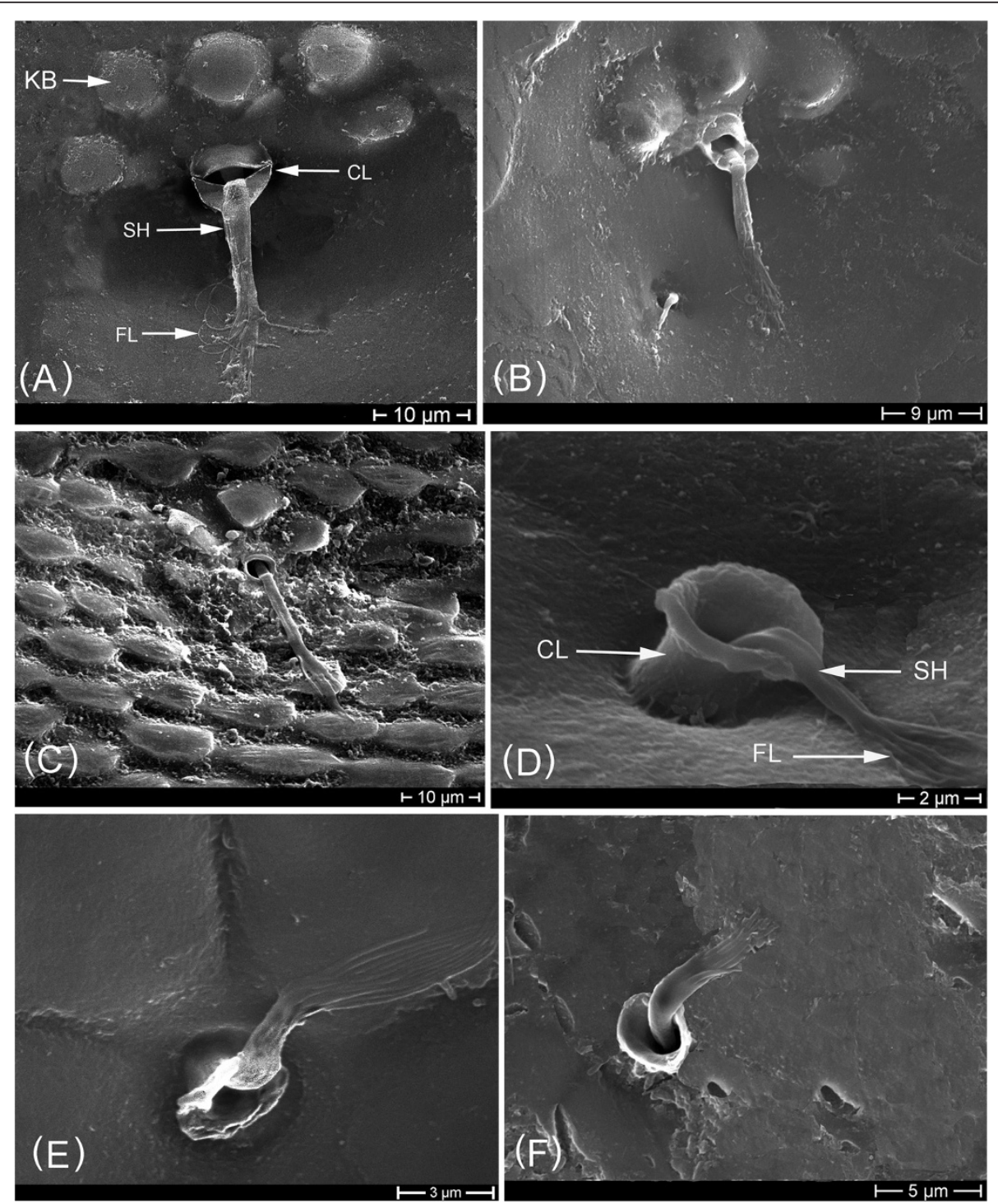

Figure 3 Scanning electron micrographs of the microtrich structures of Excirolana, Atarbolana, and Sphaeromopsis species.

(A) Excirolana sp. from the Persian Gulf. (B) Excirolana orientalis (from Nagada, New Guinea), (C) Atarbolana sp. from the Persian Gulf, Iran. (D) Sphaeromopsis sarii. (E) Sphaeromopsis amathitis. (F) Sphaeromopsis mourei. CL, collar; SH, shaft; FL, filament; KB, knob. 
distal part, and S. amathitis 10 to 12 filaments (Figure 3E). D. granulata Javed and Ahmed 1988 similar to the genus Sphaeromopsis has also six rows of microtrichs (Figure 1D). However, on D. granulata, the number of distal filaments is less (approximately five filaments), and the shaft is shorter (Figure 4C).

In contrast to the previous taxa, on S. khalijfarsi Khalaji-Pirbalouty and Wägele 2010, microtrichs are located in ten rows (rather than six rows), and there are two rows on the mid-dorsal surface of the pleotelson and one row on each marginal surface (Figure 1C). Each microtrich bears a short cuticular collar, an elongate shaft and a tuft of approximately eight long distal filaments (Figures 2F and 4A). Similarly, on S. walkeri Stebbing 1905, each structure has a short collar, a long shaft, and a few distal filaments (Figure 4B). However, on Cymodoce sp., each structure possesses a longer collar, very long shaft, and long distal filaments (Figures 2G and 4D).

\section{Discussion}

The cuticular microstructures of a few aquatic species of crustaceans like amphipods and isopods have been studied previously by SEM (e.g., Schmalfuss 1978; Meyer-Rochow 1980; Powell and Halcrow 1982; Holdich 1984; Laverack and Barrientos 1985; Platvoet 1985; Oshel et al. 1988;
Olyslager and Williams 1993; Halcrow and Bousfield 1987; Read and Williams 1991; Khalaji-Pirbalouty and Sari 2006; Zimmer et al. 2009; Kaim-Malka 2010). The majority of these studies investigated the cuticular surface of Amphipoda, and only few attempts have been conducted to study the microscopic structures on the tegument surface of aquatic isopods (e.g., Wägele 1993; Escobar et al. 2002; Brandt 1988; Kaim-Malka 2010). Different types of cuticular structures such as scales, setae, microtrichs, setules, pores, or denticles were observed in marine isopods. Of these, microtrich sensilla type II were found only in a few marine isopods. However, microtrich sensilla type II were observed in several amphipods (Platvoet 1985; Oshel et al. 1988; Zimmer et al. 2009; Kaim-Malka 2010). Recently, Kaim-Malka (2010) found similar kinds of microtrich sensilla type II in Eurydice truncata (Norman 1868) and Natatolana borealis (Lilljeborg 1851) and named them as 'unispathes'. The structures reported here are very similar to type Ib microtrichs (sensu Oshel et al. 1988) reported for Amphipoda. However, the type Ib microtrichs reported here differ from those observed by previous authors for the majority of amphipods and also some isopods, because they have a cuticular collar that arises from the cuticular surface in the basal part of the seta. Moreover, the type $\mathrm{Ib}$ microtrichs reported here are
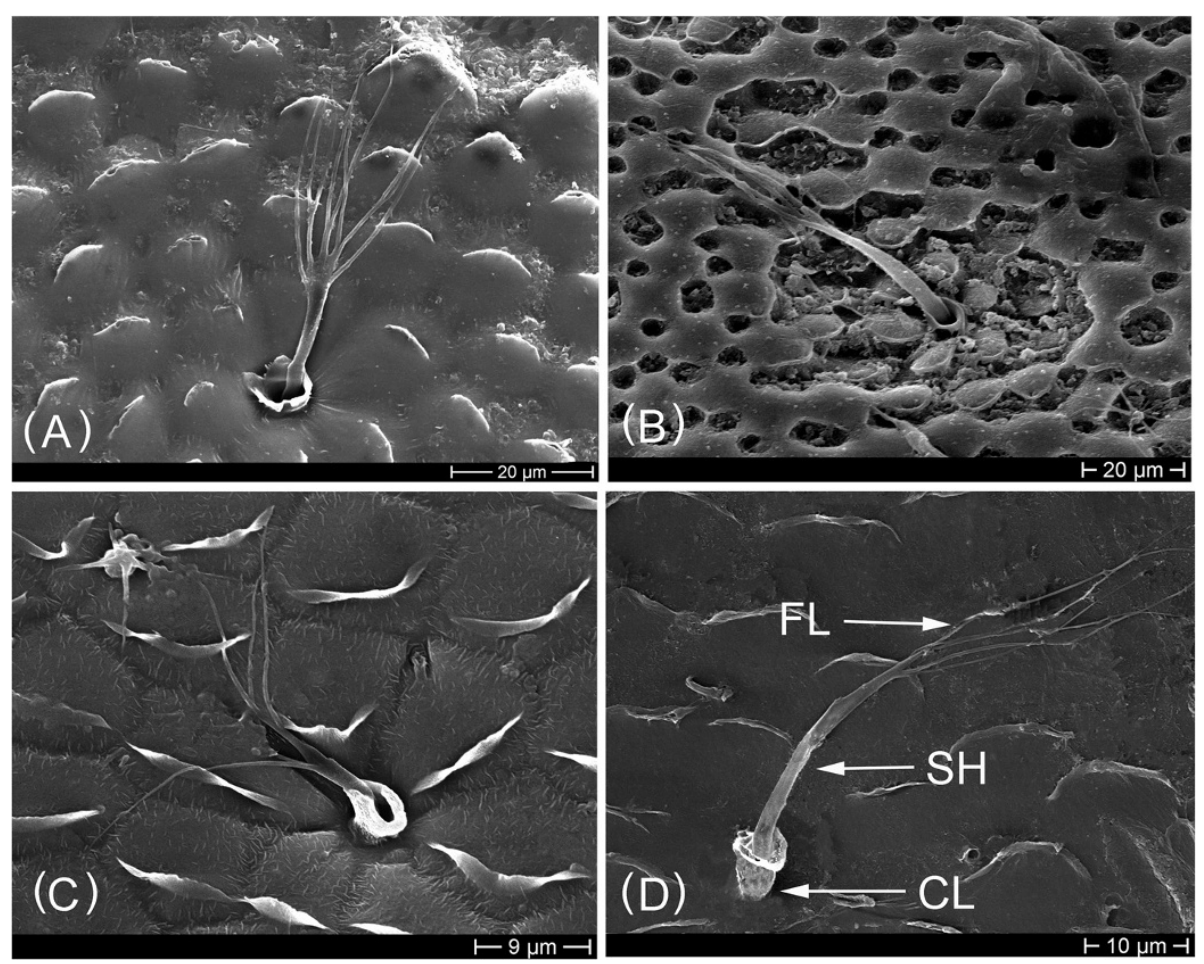

Figure 4 Scanning electron micrographs of the microtrich structures of Sphaeroma, Dynamenella, and Cymodoce species. (A) Sphaeroma khalijfarsi (with short collar and shaft, long filaments). (B) Sphaeroma walkeri (with short collar, long shaft, long filaments). (C) Dynamenella granulata (with short collar and shaft, long filaments). (D) Cymodoce sp. (with medium collar, very long shaft and filaments); CL, collar; SH, shaft; FL, filament. 
arranged in regular and symmetrical rows on the body surface. Microtrich sensilla type II were not found in any species in this study. Kaim-Malka (2010) reported microtrich sensilla type II in the marine isopods E. truncata Norman 1868 and $N$. borealis Lilljeborg 1851, both species are found in marine subtidal environments. E. truncata is restricted to depths of 50 to $200 \mathrm{~m}$ (Schotte 2012), and $N$. borealis is found more broadly at 5 to $1,478 \mathrm{~m}$ (Keable and Bruce 1997; Johansen and Brattegard 1998). These data suggest that microtrich sensilla type II may characterize swimming species. In addition, Kaim-Malka (2010) stated that this structure may be less well developed or completely absent among species less able to swim and living in intertidal habitats. The type Ib microtrichs reported here are well developed on the dorsal and lateral sides of the examined marine species.

A comparison of these microtrichs shows that the number of distal filaments has correlation with living habit on different habitats. The result suggests that swimming species (e.g., Excirolana and Lanocira) have microtrichs with high number of distal filaments (15 to 30 filaments), whereas cirolanid isopods living in low algal turfs over rocky shore, e.g., Atarbolana sp., have microtrichs bearing few distal filaments (approximately five). In less-able swimming sphaeromatid isopods examined here, this structure has clearly low number of distal filaments. For example, in S. walkeri, S. khalijfarsi, D. granulata (all living in burrows or beneath stones in intertidal habitats), and Cymodoce sp. (live amongst algal and seagrass beds in subtidal habitats), the microtrichs have approximately four to eight distal filaments. Whereas, in S. sarii, S. mourei, and S. amathitis (mainly occur and swim in intertidal tide pools and partly on low algal turfs), this structure has approximately 8 to 12 filaments. In conclusion, the number of distal filaments on these structures has close correlation with the habitat structure. Swimming species in water column have more filaments than low swimmer species and species that living in burrows and beneath stones in intertidal habitats. According to Halcrow and Bousfield (1987), Watling (1989), Halcrow and Powell (1992), Khalaji-Pirbalouty and Sari (2006), Zimmer et al. (2009), and Kaim-Malka (2010), the kind and number of cuticular structures represent diagnostic traits for the identification of crustaceans, e.g., copepods and amphipods, as well as isopods, both on genus and species level. Therefore, the arrangement, diversity, and morphology of these elements constitute important tools for taxonomic analyses among genera of marine isopods or among species within a genus. For example, the arrangement and number of rows of these cuticular structures, their collar shape, shaft, and the number of filaments are commonly similar in two examined species of the genus Excirolana and three species of Sphaeromopsis. However, the shape of the cuticular collar, length of shaft, and the number of filaments are different between the examined species.

There are a variety of sensory receptors that transmit information to the central nervous system of crustaceans. Among the most obvious of these sensory structures are the different types of setae and sensilla that cover various regions of the body. A mechanosensory function is suggested by several authors for these kinds of cuticular structures (Fish 1972; Rider 1978; Bush and Laverack 1982; Platvoet 1985; Brandt 1988; Wägele 1993; Escobar et al. 2002). In addition, according to Brandt (1988), Laverack (1989), Felgenhauer (1992), and Escobar et al. (2002), sensory movable setae without a terminal pore have a mechanosensory function. As the cuticular structure reported here has no terminal pore on the apical part and also due to their arrangement and distribution over the body, a mechanosensory function can be supposed. These structures may provide the animals with information about the direction and possibly velocity and changes of water currents and hydrodynamic pressure. However, further investigations are necessary to clarify in greater detail the function of these structures in marine isopods.

\section{Conclusions}

This study suggests that the new type of microtrich sensilla reported here differ from those observed by previous authors for amphipod and isopod crustaceans, in which they have a cuticular collar that arises from the cuticular surface in the basal part of the seta. They are arranged in regular and symmetrical rows on the body surface. Notably, this structure with a relatively small number of distal filaments was observed in species with lower swimming ability.

\section{Competing interests}

The author declares that he has no competing interests.

\section{Acknowledgments}

I am very grateful to Dr. J. Olesen (Zoologisk Museum, University of Denmark, Copenhagen) and Mr. D. Potter (Museum of Tropical Queensland) for the loan of material. I thank especially Prof. J. W. Wägele (Zoologisches Forschungsmuseum Alexander Koenig, Bonn, Germany), Dr. F. D. Ferrari (retired), Mrs. M. Schotte (Smithsonian Institution Natural Museum of Natural History) for providing useful comments and language editing. Anonymous referees are appreciated for reviewing the manuscript and providing valuable comments and advices.

Received: 10 August 2013 Accepted: 6 January 2014

Published: 27 January 2014

\section{References}

Brandt A (1988) Morphology and ultrastructure of the sensory spine, a presumed mechanoreceptor of Sphaeroma hookeri (Crustacea, Isopoda), and remarks on similar spines in other peracarids. J Morph 198:219-229

Bush BMH, Laverack GA (1982) Mechanoreception. In: Atwood HL, Sanderman DL (ed) The biology of crustacea, vol 3. Academic, New York

Dana JD (1853) Crustacea. In: (ed) United States Exploring Expedition during the years 1838, 1839, 1840, 1841, 1842, under the command of Charles Wilkes, U.S.N, 13th edition. pp i-viii. 1-685 (1852), 686-1618 (1853)

Escobar E, Oseguera L, Vázquez-Nin GH, Alcocer J (2002) The external micro-anatomy of the cephalon of the asellotan isopod Creaseriella anops. Hydrobiol 467:57-62 
Felgenhauer BE (1992) External anatomy and integumentary structures. In: (ed) Decapod crustacea. Microscopic anatomy of the invertebrates, vol 10. Wiley-Liss, New York, pp 7-43

Fish S (1972) The setae of Eurydice pulchra (Crustacea, Isopoda). J Zool 166:163-177

Halcrow K, Bousfield EL (1987) Scanning electron microscopy of surface microstructures of some gammaridean amphipod crustaceans. J Crust Biol 7:274-287

Halcrow K, Powell CVL (1992) Ultrastructural diversity in the pore canal systems of amphipod crustaceans. Tissue Cell 24(3):417-436

Holdich DM (1984) The cuticular surface of woodlice: a search for receptors. Symp Zool Soc Lond 53:9-48

Holdich DM, Jones DA (1973) The systematics and ecology of a new genus of sand beach isopod (Sphaeromatidae) from Kenya. J Zool 171:385-395

Holdich DM, Lincoln RJ (1974) An investigation of the surface of the cuticle and associated sensory structures of the terrestrial isopod, Porcellio scaber. J Zool 172:469-482

Javed W, Ahmed R (1988) Two new species of the genus Dynamenella from the northern Arabian Sea (Isopoda). Crustaceana 55:234-241

Johansen PO, Brattegard T (1998) Observations on behaviour and distribution of Natatolana borealis (Lilljeborg) (Crustacea, Isopoda). Sarsia 83:347-360

Kaim-Malka RA (2010) The spatheform organ: a ballasting organ in crustacean Peracarid species (Amphipods and Isopods). Memorie del Museo Civico di Storia Naturale di Verona - 2, serie. Sezione Scenziedelle vita 20:3-68

Keable SJ, Bruce NL (1997) Redescription of the North Atlantic and Mediterranean species of Natatolana (Crustacea: Isopoda: Cirolanidae). J Mar Biol Assoc UK 77(3):655-706

Khalaji-Pirbalouty V, Sari A (2004) Biography of amphipods (Crustacean: Amphipoda: Gammaridae) from the central Zagros Mountains, Iran with description of two new species. J Natur Hist 38:2425-2445

Khalaji-Pirbalouty V, Sari A (2006) Description of Gammarus baloutchi n. sp. (Amphipoda: Gammaridae) from Iran, based on light and electron microscopy. Zool Med Leiden 8:91-100

Khalaji-Pirbalouty V, Wägele JW (2010) A new species and a new record of Sphaeroma Bosc, 1802 (Sphaeromatidae: Isopoda: Crustacea) from intertidal marine habitats of the Persian Gulf. Zoota 2631:1-18

Laverack MS (1989) The diversity of chemoreceptors. In: Atema J, Fay RR, Popper AN, Tavolga WN (ed) Sensory biology of aquatic animals. Springer, New York, pp 287-312

Laverack MS, Barrientos Y (1985) Sensory and other superficial structures in living marine crustaceans. T Roy Soc Edin-Earth 76:123-136

Lilljeborg W (1851) Norges crustaceer, 8th edition. Ofversigtaf Kongliga Vetenskapsakademiens, Forhandlingar, Stockholm, pp 19-25

Loyola e Silva JD (1960) Sphaeromatidae do litoral Brasiliero (Isopoda: Crustacea). Bolet da Univers do Parana Zoolog 4:1-182

Meyer-Rochow VB (1980) Cuticular surface structures in Glyptonotus antarcticusa marine isopod from the Ross Sea (Antarctica). Zoomorphologie 94:209-216

Norman AM (1868) On two isopods, belonging to the genera Cirolana and Anilocra, new to the British Islands. Ann Mag Natural History 42:421-422

Olyslager NJ, Williams DD (1993) Function of the type II microtrich sensilla on the lotic amphipod, Gammarus pseudolimnaeus Bousfield. Hydrobiol 259:17-31

Oshel PE, Steele DH (1988) Comparative morphology of Amphipod setae, and a proposed classification of setal types. Crustaceana 13:90-99

Oshel PE, Steele VJ, Steele DH (1988) Comparative morphology of amphipod microtríquia sensilla. Crustaceana 13:100-106

Platvoet D (1985) Slide-line organ in gammarid (Crustacea: Amphipoda). Beaufortia 35(7):129-133

Platvoet D, Song Y, Li S, Van der Velde G (2007) Description of the lateral line organ of Dikerogammarus villosus (Sowinsky, 1894), with discussion on its function (Peracarida, Amphipoda). Amphipod Pilot Species Project (AMPIS)-Report 4. Crustaceana 80(11):1373-1392

Powell CVL, Halcrow K (1982) The surface microstructure of marine and terrestrial isopods (Crustacea, Peracarida). Zoomorphologie 101:151-164

Read AT, Williams DD (1991) The distribution, external morphology, and presumptive function of the surface microstructures of Gammarus pseudolimnaeus (Crustacea: Amphipoda), with emphasis on the calceolus. Can J Zool 69:853-865

Rider H (1978) Die Sinnesorgane der Antennula von Ligidiumhypnorum (Cuvier) (Isopoda, Crustacea). Zool Jahrb Anat Ontog Tiere 100:514-541

Schmalfuss H (1978) Morphology and function of cuticular micro-scales and corresponding structures in terrestrial isopods (Crust., Isop., Oniscidea). Zoomorpholgie 91:263-274
Schotte M (2012) World marine, freshwater and terrestrial isopod crustaceans database. Available via World Register of Marine Species. http://www. marinespecies.org/aphia.php? $p=$ taxdetails\&id=118855. Accessed 23 April 2013

Stebbing TRR (1905) Report on the Isopoda collected by Professor Herdman at Ceylon, in 1902. Report to the Government of Ceylon on the Pearl Oyster Fisheries of the Gulf of Manaar, Supplementary Report 4. In: (ed). Supplementary Reports, 23. pp 1-64

Steele VJ (1991) The distribution and frequency of the type II microtrichs in some gammaridean amphipods. Hydrobiolo 223:35-42

Wägele JW (1993) Isopoda. In: Harrison FW, Hames AG (ed) Crustacea. Microscopic anatomy of invertebrates, vol 9. Wiley-Liss, New York, pp 529-617

Watling $L$ (1989) A classification system for crustacean setae based on the homology concept. In: Felgenhauer BE, Watling L, Thistle AB (ed) Functional morphology of feeding and grooming in crustacea. Crustacean issues 6. A. A. Balkema, Rotterdam, pp 15-26

Zimmer A, Araujo PB, Bond-Buckup G (2009) Diversity and arrangement of the cuticular structures of Hyalella (Crustacea: Amphipoda: Dogielinotidae) and their use in taxonomy. Zoologia 26(1):127-142

doi:10.1186/1810-522X-53-7

Cite this article as: Khalaji-Pirbalouty: The morphology, arrangement, and ultrastructure of a new type of microtrich sensilla in marine isopods (Crustacea, Isopoda). Zoological Studies 2014 53:7.

\section{Submit your manuscript to a SpringerOpen ${ }^{\circ}$ journal and benefit from:}

- Convenient online submission

Rigorous peer review

- Immediate publication on acceptance

- Open access: articles freely available online

- High visibility within the field

- Retaining the copyright to your article

Submit your next manuscript at $>$ springeropen.com 